属によるもの 2 部位 2 例 $0.9 \%$ ，胃腸管内空気によるもの 5 部位 5 例 $2.2 \%$ ，動䏡の拍動性厓迫によるもの32部位26例 $11.5 \%$ っ た. 血管圧迫の黄任動脈は，右肝動脈が最も多く，固有肝動䛲，胆

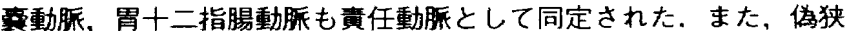
窄を疑う時は，脂肪㧕制なしの画像を追加することにより同定が可 能であった。

55 MR cholangiopancreatographyにおける経口陰性造影 郕としてのFerriseltzの使用について

医療法入あかね会土谷総合病院 楠 貴宏，他 3 名

MRCPを用いた撮影で、消化管内の高信号となる障害陰影を高 湮度フェリセルツ溶液を服用することで消失することは可能か否か 検討しました，標準濃度から10倍濃度のフェリセルツ溶液の信号 強度変化と、胃液の量の変化に対しての信号強度変化を測定した. そして実際に健常ボランティア 6 人に服用してもらい服用後 5 分、15分、30分で撮像を行ない，視覚的に評価を行った。結果， 6 倍濃度の $100 \mathrm{ml}$ で服用し、服用後 5 分から 15 分以内に撮影する のが罗も効果が表われる。

\section{6 fast-FLAIR法によるくも膜下出血の評価}

島根県立中央病院 岩崎一人，他 4 名

【目的lfast-FLAIR法による，くも膜下出血の描出能を評価するた め、人静腺血と生理食塩水で模擬ファントムを作成し，簡単な基礎 実験をふまえ，X線CTとMRIを視覚的に評価し，有用性と問題点 について検討した。

【結果】(基礎的検討でMRIはX線CTよりも低濃度の血液を検出出来 る可能性を示㖫した。(2MRIがX線CTと比べて，後頭蓋，脳幹周 囲，およひ頭頂部において，やや優れていた，FLAIR法を追加する ことで、軽症患者のスクリーニングでも、くも膜下出血を検出出来 る可能性があると思われた。

57 IR EPI FLAIRのパルスシーケンスの検討

広島大学医学部附属病院 高羽順子。他 3 名

ファントムおよび正常者において，IREPIによる撮影条件の検討 を、TR $11900 \mathrm{~ms}$ とTE $120 \mathrm{~ms}$ を一定にしTIとshot数を変えて行 つた。 1 shotと s2 shotでは, 2200〜2400ms, 4 shotでは, 1800 2000msのTIで，脳脊椎液の信号が抑制され，白質と灰白 兵のコントラスト比も良効であった，EPIFLAIR法は，従来のfast FLAIR法に比べ，静磁場の均一性や磁化率の違いによる影䉒を受け やすいが，簡便に短時間で撮影でき脳脊骫液の信号に影整されやす い脳皮熼病变や脳室周囲の病变の評価に有用と思われた。

\section{EPIによる拡散強調画象の有用性}

岡山大学医学部附属病院 北山卓一, 他 6 名

【目的】拡散強調画像は生体内の水分子のランダムな運動を画像化し たものである、今回EPIシーケンスを用いた拡散強調画像に関し て，水，アセトンによる基礎的検討および臨床応用も試みた。

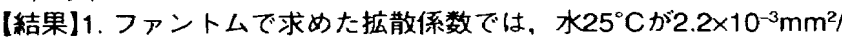
$\mathrm{sec}$ 、アセトンが $4.7 \times 10^{-3} \mathrm{~mm}^{2} / \mathrm{sec}$ となり文献上の值とよく一致し

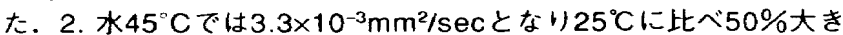
な值となり，拡散係数の温度による变化も確認できた。3. 急性期 脳梗塞の臨床において、梗塞部位の描出は他のシーケンスよりも良 好であり、bファクタを大きくすると，より強調された拡散強調画 像を得た. 4. 脳虚血の早期診断に有用であった。

MR : III

\section{座長 岡山大学医学部附属病院 北山卓一}

\section{FFE法を用いた上榎部のT、強調画像}

松江生協病院 松畸千佐子, 他 2 名

上腹部の丁、強調画像において, 呼吸によるモーションアーチファ クトを軽減する方法として、いくつかの方法があり，当院では位相 エンコードアーチファクト除去法を用いたSE法を使用していた。 しかし、呼吸の不規則な患者は十分に呼吸補正がかからず、アーチ ファクトの多い画像になる. 今回，われわれは通常ダイナミック撮 影に使用しているFFE法を応用し、T、強調撮影を行うことで呼吸に よるアーチファクトの軽減を試みた．結果は全症例でアーチファク トは消失し、SOLの検出能は向上した。また，質的診断でもその 有用性が示㖫された。
60 IR EPIの臨床応用(第 1 報)一上榎部領域についてー 広島大学医学部附属病院高羽順子。他 3 名

上腹部において，IR EPI法でTIを変化させ得られた画像が診断 に応用できるか検討を行った。息止め下でTは変えて得られた画像 は, 短時間で䑏器のコントラストの調整が可能であり、T2強調画像 およびT、強調画像で肝臟と識別困難な肝癌など腹部病変の質的診断 に有用と思われた. dynamic scanにおいて、IREPI法は従来の撮 影法に比べ，空間分解能が低く，磁化率の違いによるアーティファ クトの影䈏を受けやすいため、形態診断への応用は難かしい.

\section{GRASE法を用いたT、強調画像の下腹部領域への応用} 弇敷中央病院 清野 隆，他 6 名

【目的】下腹部領域においてGRASE法を用いたT、強調画像を、SE 法T1強調画像と比較し、臨床応用の検討を行う。

【方法】卵巣チョコレート豪胞、卵巣皮様腫に対し、SE法と GRAS法でT1強調画像とその脂肪抑制画像を撮像し、病变描出能, 画質およびアーチファクトについて視堂的評価および定量評価を行 つた.

【結果】GRASE法T、強調画像は，SE法T1強調画像に比べ，䑏器間 コントラストはやや出るが，病変描出能はほぼ同等であった。 SE 法に比べァーチファクトが少なく，画䅡評価もほぼ同等であった。 【考察】GRASE法は撮像時間が短く、高速SE法に比しSARも低く 下腹部領域における高速撮像法として有用である。

\section{2 脂肪抑制TGSEの前立眿への利用}

(財)倉敷成人病センター小橋高郎，他 2 名

脂肪抑制TGSEを前立腺に使用し，良好な結果を得たので報告す る. 前立腺癌症例を対象としたTGSEでは，1)他のT2強調画像に比 べ内腺外腺比が高い，2）外腺内限局の腫瘍と正常域のCNRが高 い，3）外腺全体に信号低下のある症例で，内腺外腺比が高い，4） 治療経過観察中の症例で，外腺高信号の回復に敏感な傾向がみられ るといった利点があり、高速SEを使用した高T2強調画像の欠点を 短時間の追加で㭪うことができる。したがって前立腺MRI診断では 高分解能T2強調画像に脂肪抑制TGSEを加えることによって、診断 能向上に寄与できると思われる

\section{3 超音波検奋による内膜脂肪の評価法一睤間膜像の検討一}

(財)倉敷成人病センター 渡辺敏充。他 4 名

肥満は，糖代謝異常・脂質代謝異常・高血圧などの合併症を高率 に発症する. 肥満とこれらの疾患との因果関係については、肥满者 の脂肪組織の分布異常、特に腹腔内の内䑏脂肪の蓄積が密接に関係 していることがわかり，注目を集めている．われわれは，内䑏脂肪 の評価法として、晹間膜像を検討した．晹間膜の組織像摘出標本の 超音波像と経腹による腸間膜の超音波像を比較、腸間膜厚の測定を 行い，肥満度と脂肪肝を指標として検討した。肥满度の增加に伴い 腸間膜厚の肥厚がみられ，男女差があった。脂肪肝では男女差なく 肥厚がみられた．腸間膜厚は内臓脂肪の程度をよく反映し，その評 価法として有用である。

MR : IV

座長 広島大学医学部附属病院 高羽順子

64 MR dynamic subtraction angiography (MRDSA) 倉敷中央病院 熊代正行, 他 6 名

Gd-DTPA造影剂を用いたMRAの骨盤およひ不肢領域における動 脈の描出能について検討を行った. 三次元高速グラディエントエコ 一法を用いることにより，短時間撮像を可能にした。また、ボーラ ス静注によるfirst pass imagingを試み、更に，画像処理にサブト ラクション法を応用することで少量 $(0.02 \sim 0.06 \mathrm{mmol} / \mathrm{kg} /$ 部位，計 $0.1 \mathrm{mmol} / \mathrm{kg}$ )の造影郕で腹部から下腿をでの広範囲な動脈を描出す る方法としてMRDSA (MR dynamic subtraction angiography) 考案した．本法は脂肪織の信号や，折り返しアーチファクトも抑制 することが可能であり，特に広範な動腺像が必要とされる閉塞性動 脈硬化症や動脈瘤の描出において有用であった。

65 Gd-DTPA造影による呼吸停止下大動眽3DMR angiographyについて

医療法人あかね会 土谷総合病院今田直幸，他 3 名

胸部大動脈に対しGd-DTPAを急速静注し呼吸停止下の3DMRA と心電同期の 2D-TOF-MRAを行った. 6 症例よりその有用性を比 較検討した。大動脈弓部の倍号強度はGd-3D-MRAの方が明らかに 